KRZYSZTOF JAKUBIAK

Uniwersytet Gdański

WIESEAW JAMROŻEK

Uniwersytet im. Adama Mickiewicza

w Poznaniu

\title{
DZIEJOWE KONTEKSTY \\ ORAZ TENDENCJE REFORM SZKOLNYCH \\ NA ZIEMIACH POLSKICH OD XVIII DO XX WIEKU (DO 1939 ROKU)
}

\begin{abstract}
Jakubiak Krzysztof, Jamrożek Wiesław, Dziejowe konteksty oraz tendencje reform szkolnych na ziemiach polskich od XVIII do XX wieku (do 1939 roku) [Historical Concepts and Tendencies of Educational Reforms in Polish Territories From the 18th till 20th Century (Until 1939)]. Studia Edukacyjne nr 32, 2014, Poznań 2014, pp. 7-19. Adam Mickiewicz University Press. ISBN 978-83-232-2837-0. ISSN 1233-6688

The authors of the essay present both historic dimensions and main tendencies of organizational assumptions and curricular educational reforms in Polish territories from the Enlightenment till the Second World War.

Research shows that challenges of civilization, changes of the sets of upbringing and attempts to offer democratic access of society to education were factors which stimulated and directed the processing of educational reforms in then Europe, Poland included. The main educational reforms were initiated by processes of social and political changes. The state was the mainspring of educational reforms in Europe of modern times. During the Enlightenment, the state took over schools, which resulted in adopting an act establishing the National Education Commission. In the Duchy of Warsaw, the Educational Association created a framework of educational administration connected with the social factor of school supervision. The development of educational legislation took place in the second half of the 19th century. At that time education in Polish territories was connected with the schooling systems of the invaders. The reforms initiated by Poles were to modernize the Polish nation and strengthen its social, political and economic condition. The educational reforms in Poland after regaining Independence were to help rebuild, modernize and strengthen the reborn state.
\end{abstract}

Key words: educational reforms, Polish territories from the 18th till 20th century

Jedną z istotnych cech Europy nowożytnej był fakt permanentnego postulowania reform edukacyjnych i ich, dokonywanego zazwyczaj z pewnym wobec postulatów opóźnieniem i niekoniecznie zgodnej z założeniami skali, urzeczywistniania. Reformom oświatowym towarzyszyło często nazbyt 
optymistyczne przekonanie, oparte na głębokiej wierze, że szkoła ma ogromne możliwości sprawcze, nie tylko w zakresie kształtowania losu pojedynczych ludzi, ale także całych społeczeństw, państw i wreszcie ludzkości¹.

Czynnikami stymulującymi i ukierunkowującymi przebieg reform edukacyjnych w nowożytnej Europie, w tym również w Polsce, były m.in.: wyzwania cywilizacyjne, zmiany ideałów wychowawczych, dążenia do demokratyzowania dostępu społecznego do oświaty, poszukiwania modelu optymalnej organizacji szkolnictwa oraz wprowadzenia zmian programowych treści edukacyjnych oraz zastosowania skuteczniejszych metod nauczania i wychowania. Generalnie jednak, reformy szkolnictwa były i są wywoływane lub wymuszane przez procesy przemian kulturowych, społecznych i politycznych. Bardzo ważnym czynnikiem reform edukacyjnych w Europie czasów nowożytnych i najnowszych stało się państwo, rozumiane w sensie politycznej formy bytowania narodu i systemu władzy. W Polsce związek ten miał specyficzny charakter, bowiem od czasów Odrodzenia - XVI wieku dyskusje oraz decyzje dotyczące szkół i edukacji młodzieży cechował prymat potrzeb i wartości społeczno-politycznych, państwowych przed pedagogicznymi². Problem związku szkolnictwa i wychowania młodzieży z kompetencją i dobrobytem państwa był już poruszany w pismach politycznych polskiego Odrodzenia, zwłaszcza przez Andrzeja Frycza Modrzewskiego w jego dziele zatytułowanym $O$ naprawie Rzeczypospolitej ( $D e$ Republica emendanda, 1551). Wiążąc wychowanie z działalnością państwa, A. Frycz Modrzewski pragnął reformować państwo poprzez edukację szkolną. Nawrót do powszechnego zainteresowania tą tematyką nastąpił w pismach i polemikach polskiego Oświecenia. Szczególnie zajmował się nią w swych pismach i działalności pedagogicznej ks. Stanisław Konarski ${ }^{3}$.

Reformy oświaty inicjowane i realizowane w Polsce w wieku XVIII, zwłaszcza w czasie funkcjonowania Komisji Edukacji Narodowej (17731794), pierwszego w świecie ministerstwa oświaty, łączyły się z dążeniem państwotwórczych środowisk do wzmocnienia i modernizacji państwa. Reformy te miały ustrzec państwo polskie przed rozkładem, czy wręcz przed jego upadkiem, łącząc się z programem jego naprawy. Takie intencje przyświecały m.in. próbom reform szkolnych podjętych przez wymienianego powyżej Stanisława Konarskiego jeszcze w pierwszej połowie tego stulecia. Stanisław Konarski dokonując reformy szkolnictwa pijarskiego „zmierzał do

${ }^{1}$ A. Smołalski, Teleologia reform edukacyjnych $w$ nowożytnej Europie i w Polsce, [w:] Reformy edukacyjne w Polsce, red. I. i G. Michalscy, Skierniewice 2001, s. 27.

2 K. Bartnicka, Państwo i edukacja w polskich reformach szkolnych XVIII-XX wieku, [w:] Państwo a edukacja, red. J. Kochanowicz, T. Tokarz, Wrocław 2008, s. 24.

${ }^{3}$ Tamże. 
tego, by szkoła służyła potrzebom życia społecznego, i to w sensie przysposobienia młodzieży do naprawy tego wszystkiego, co w istniejących warunkach w Polsce wydawało mu się złe i szkodliwe" 4 . W reformowanym przez niego szkolnictwie zakonu pijarów szczególny nacisk położony został na edukację obywatelską - kształtowanie obywatela, który miał rozumieć teraźniejszość własnego kraju i najważniejsze zadania na przyszłość. Starano się rozszerzyć program nauczania o treści z dziedziny historii i geografii, prawa i nauki o państwie. Charakterystyczny pozostaje fakt, że S. Konarski wśród polecanych autorów odwoływał się do czołowych myślicieli epoki Oświecenia, m.in. do francuskiego filozofa Voltaire'a.

Naprawie państwa miała służyć działalność reformatorska wspomnianej już Komisji Edukacji Narodowej, kontynuująca m.in. starania reformatorskie Stanisława Konarskiego i dokonująca się w czasie swoistego przewrotu umysłowego $\mathrm{w}$ Polsce ostatnich dekad XVIII stulecia. W naszym kraju w tym czasie, podobnie jak już wcześniej w zachodniej Europie, zyskiwała coraz większe uznanie charakterystyczna dla epoki Oświecenia filozofia postępu, nauki i oświaty. Również w Polsce zaczęto przypisywać nauce i edukacji rolę promotora pożądanych przemian społecznych i politycznych. W konsekwencji, rozwijano działania zmierzające do popularyzacji wiedzy o świecie i krzewienia nauki „użytecznej krajowi”. W ten wzrastający „front odrodzenia umysłowego" 5 poczęły się wpisywać reformy wychowania realizowane przez Komisję Edukacji Narodowej.

Komisja Edukacji Narodowej powstała w rok po dokonaniu pierwszego rozbioru Polski, już po kasacie Towarzystwa Jezusowego - prowadzącego dotąd w Polsce większość szkół średnich, 14 października 1773 roku. Zniesienie Towarzystwa Jezusowego zagroziło bytowi szkól, ale jednocześnie stworzyło możliwości całościowego rozwiązania w Polsce problemów edukacyjnych ${ }^{6}$. Komisja obejmując zasięgiem swego „rządu edukacyjnego" cały kraj, stworzyła silne centrum organizacyjne, ze sztabem ludzi wypracowujących nowoczesne koncepcje pedagogiczne. Ów sztab ludzi (spośród których wymienić można m.in. Grzegorza Piramowicza, Antoniego Popławskiego, Hugona Kołłątaja) przygotował liczne instrukcje i przepisy dotyczące różnych odcinków reformy szkolnej, opierając się na najnowszej myśli pedagogicznej, wcielając zarazem w życie rezultaty własnych doświadczeń i przemyśleń.

${ }^{4}$ B. Suchodolski, Komisja Edukacji Narodowej na tle roli oświaty w dziejowym rozwoju Polski, Warszawa 1973, s. 85.

5 Tamże, s. 113.

${ }^{6}$ A. Jobert, Komisja Edukacji Narodowej w Polsce (1773-1794), Wrocław 1979, s. 11. 
Komisja Edukacji Narodowej stworzyła nowy kształt polskiego szkolnictwa, opartego na tych samych założeniach programowych i nadzorowanego przez państwo. Zarazem, przewidziano odrębne zadania dla każdego szczebla szkolnego. Szkoły akademickie, nazwane z czasem szkołami głównymi, miały obok rozwoju badań naukowych zajmować się popularyzacją ich wyników, nauczaniem, sprawowaniem nadzoru nad pozostałym szkolnictwem. Dla szkół parafialnych, znajdujących się u dołu drabiny oświatowej, przewidziano zadanie "oświecania ludu około religii, około powinności stanu jego, około robót i przemysłu”. KEN podjęła zakończone powodzeniem działania w celu unowocześnienia treści i metod nauczania. Ważnym osiągnięciem $\mathrm{w}$ zakresie modernizacji kształcenia była koncepcja nauki moralnej i edukacji obywatelskiej. Język polski stał się zarówno językiem wykładowym, jak i odrębnym przedmiotem nauczania. Do programów nauczania wprowadzono $\mathrm{w}$ szerokim wymiarze treści $\mathrm{z}$ dziedziny nauk ścisłych i utylitarnych?

Komisja Edukacji Narodowej - której przyświecała zasada, iż „zawsze takie Rzeczypospolite będą, jakie ich młodzieży chowanie” - pozostała $\mathrm{w}$ pamięci jako jedno $\mathrm{z}$ wielkich dzieł polskiego Oświecenia. Jej dorobek stawiany był - $\mathrm{i}$ jest - na równi $\mathrm{z}$ innym wielkim polskim sukcesem tej epoki, jakim było uchwalenie Konstytucji 3 maja - jednej z pierwszych konstytucji w świecie. Duch Komisji obecny był w działaniach reformatorskich podejmowanych na ziemiach polskich $\mathrm{w}$ kolejnych okresach historycznych, w okresie porozbiorowym w pierwszej połowie XIX wieku, w czasach Księstwa Warszawskiego i tzw. Królestwa Kongresowego, także w późniejszych poczynaniach reformatorskich kontrowersyjnego (polityka ugodowego wobec zaborcy) Aleksandra Wielopolskiego z okresu poprzedzającego wybuch (w 1963 r.) narodowego powstania styczniowego w zaborze rosyjskim.

W czasach zaborów, w okresach zdecydowanej dominacji zaborców w szkolnictwie poszczególnych dzielnic polskich, władze zaborcze reformując szkolnictwo polskie dla Polaków, dostosowywały je do swoich systemów oświatowych i celów polityki realizowanej wobec ludności polskiej. Zmiany w tym szkolnictwie, jak pisze Kalina Bartnicka:

były częste, z reguły dosyć gwałtowne, zwłaszcza, gdy miały charakter represji lub akcji odwetowych za dążenia niepodległościowe Polaków. Najczęściej były sprzeczne $\mathrm{z}$ naszym interesem narodowym i nie wynikały ani z potrzeb społecznych, ani z rozwoju pedagogiki 8 .

${ }^{7}$ Zob. szerzej m.in.: B. Suchodolski, Komisja Edukacji Narodowej na tle roli oświaty; A. Jobert, Komisja Edukacji Narodowej.

8 K. Bartnicka, Państwo i edukacja, s. 25. 
W wieku XIX były jednak okresy w odniesieniu do poszczególnych dzielnic polskich, $\mathrm{w}$ których inicjatorem i realizatorem zmian oraz reform w oświacie szkolnej była strona polska.

Na początku XIX wieku, w dziejach Polski, w tzw. dobie napoleońskiej i po Kongresie Wiedeńskim (rok 1815), istniały w latach 1807-1831 namiastki polskiej państwowości, funkcjonujące pod nazwą wymienionego powyżej Księstwa Warszawskiego (1807-1815) i Królestwa Polskiego (1815-1831, określanego w polskiej historiografii także mianem Królestwa Kongresowego - oddanego cesarzowi Rosji, do 1925 r. Aleksandrowi I), zarazem królowi polskiemu. 24-letni okres istnienia dwóch kolejnych niewielkich autonomicznych organizmów „państwowych” wyznaczony był dominacją wpływów politycznych: francuskich (1807-1812), rosyjskich (1813-1830) i polskich (1830-1831). W każdym z nich sytuację polityczną i społeczną kształtowały też różne czynniki, które wywierały z kolei wpływ na organizację i funkcjonowanie szkolnictwa9 ${ }^{9}$.

Należy podkreślić, że za reformami Izby Edukacyjnej w Księstwie Warszawskim (1807-1814) i tzw. Królestwie Kongresowym po 1815 roku stała samodzielna polska myśl. Reformy szkolne z tego okresu przeprowadzane były przez Izbę, a potem przez Komisję Rządową Wyznań Religijnych i Oświecenia Publicznego, będącymi państwowymi władzami oświatowymi, które "otwarcie nawiązywały do osiągnięć i intencji Komisji Edukacji Narodowej"10.

Izba Edukacyjna (1807-1811) i jej następczyni - Dyrekcja Edukacji Narodowej (1811-1815) Księstwa Warszawskiego doprowadziły do stworzenia nowoczesnego, szczeblowego i drożnego systemu oświatowego. U jego podstaw legły oświeceniowe zasady powszechnej dostępności do oświaty, jej świeckości - polegającej na przejęciu kierownictwa i nadzoru nad szkolnictwem przez władze państwowe oraz jednolitości organizacyjnej i programowej szkolnictwa. Zapoczątkowany został również proces demokratyzacji szkolnictwa ponadelementarnego, ograniczony jednak istnieniem opłat szkolnych ${ }^{11}$. Ponadto, mimo niesprzyjających warunków ekonomicznych zdołali Polacy w Księstwie Warszawskim rozbudować szkolnictwo wszystkich szczebli organizacyjnych.

Większość szkół Księstwa Warszawskiego znalazła się po Kongresie Wiedeńskim w granicach Królestwa Polskiego. Komisja Rządowa Wyznań Religijnych i Oświecenia Publicznego Królestwa (1815-1831), kierowana

${ }^{9}$ A. Winiarz, Szkolnictwo Księstwa Warszawskiego i Królestwa Polskiego (1807-1831), Lublin 2002, s. 9.

${ }^{10}$ K. Bartnicka, Państwo i edukacja, s. 32.

${ }^{11}$ A. Winiarz, Szkolnictwo Księstwa Warszawskiego i Królestwa Polskiego, s. 521-522. 
w pierwszych latach jej istnienia przez byłego kierownika władz oświatowych Księstwa - Stanisława Kostkę Potockiego, kontynuowała główne kierunki polityki oświatowej Izby Edukacyjnej i Dyrekcji Edukacji Narodowej. Zgodnie $\mathrm{z}$ ciągle jeszcze żywym na ziemiach polskich duchem fizjokraty$\mathrm{zmu}$, priorytetowo traktowano sprawę oświaty elementarnej (przeznaczonej głównie dla ludu).

Największym osiągnięciem władz oświatowych Królestwa Polskiego było utworzenie Uniwersytetu Warszawskiego, a Warszawa przestała być jedną z nielicznych już wówczas stolic europejskich, które nie miały uniwersytetu. Uporządkowano również organizację i funkcjonowanie prywatnych placówek kształcenia dziewcząt oraz powołano Instytut Rządowy Wychowania Płci Żeńskiej. Również, sięgające czasów Księstwa Warszawskiego, plany zorganizowania szkół zawodowych, zarówno cywilnych, jak i wojskowych, zostały urzeczywistnione w istocie dopiero w Królestwie ${ }^{12}$.

Ustawodawstwo szkolne, zarówno Księstwa, jak i Królestwa, sankcjonowało funkcjonowanie dozorów szkolnych i organów samorządu szkolnego wszystkich szczebli terytorialno-oświatowych, w których reprezentowani byli przedstawiciele miejscowego społeczeństwa, $\mathrm{w}$ tym także rodzice uczniów uczęszczających do lokalnych szkół. Istotny jest fakt, że od XIX wieku sprawy oświaty publicznej przestawały być dziedziną kompetencji Kościoła i duchowieństwa, względnie tylko urzędników państwowej administracji oświatowej. Stawały się odtąd kwestią społeczną. Organy samorządu szkolnego, począwszy od XIX-wiecznych dozorów, zapoczątkowały trwający do dzisiaj trudny proces odformalizowania i decentralizacji zarządzania szkołą i oświatą w Polsce oraz nadawania jej charakteru społecznego's.

Wspominany powyżej Aleksander Wielopolski w okresie widocznych przejściowych ustępstw zaborcy rosyjskiego (przełomu lat pięćdziesiątych i sześćdziesiątych) przeprowadził w roku 1862 Ustawę o wychowaniu publicznym, dzięki której zreorganizowano szkolnictwo na wszystkich jego szczeblach. Nawiązując do tradycji z czasów KEN i reform z początków XIX wieku, otoczono wówczas szczególną opieką szkolnictwo elementarne, ustalono możliwości przechodzenia z tego szczebla na poziom średni, stworzono na nowo zasady sieci szkolnej i administracji oświatowej, zorganizowano, również na nowo, szkolnictwo wyższe, tworząc w Warszawie Szkołę Główną, a następnie Instytut Politechniczny i Rolniczo-Leśny w Puławach ${ }^{14}$.

12 Tamże, s. 524-525.

${ }^{13}$ K. Jakubiak, Instytucje samorzadu szkolnego w reformach oświatowych na ziemiach polskich w XIX w. oraz w II Rzeczypospolitej, [w:] Reformy edukacyjne, s. 97-107.

14 K. Poznański, Wybrane zagadnienia z historii wychowania, t. 2, Warszawa 2006, s. 145-148; szerzej w: K. Poznański, Reforma szkolna w Królestwie Polskim w 1862, Wrocław 1968. 
Niestety, reforma została zatrzymana przez wybuch powstania styczniowego, a po jego upadku nastąpiła w zaborze rosyjskim szeroka fala represji wobec narodu polskiego, również w dziedzinie oświaty.

Oświata w trudnych warunkach niewoli narodowej w XIX wieku stawała się znaczącym orężem walki z zaborcami, zwłaszcza w ostatnich dekadach tego stulecia. Odgrywała ona ważną rolę również w autonomicznej Galicji, w której dokonywano reform oświaty, z uwzględnieniem - w istotnej mierze - interesów narodowych jej polskich mieszkańców. Charakterystyczne, że kiedy rusyfikowano szkolnictwo w zaborze rosyjskim, a germanizowano je w zaborze pruskim (gdzie szkolnictwo to kompensowały polskiemu społeczeństwu różne formy oświaty pozaszkolnej), w tej dzielnicy polskiej królował w szkołach język polski. Na początku poczynań reformatorskich w zaborze austriackim ważną rolę odegrało dzieło Józefa Dietla, rektora Uniwersytetu Jagiellońskiego, O reformie szkół krajowych. Dzięki zabiegom Dietla i poparciu innych środowisk, sejm galicyjski powołał do życia - po akceptacji władz z Wiednia w 1867 roku - Radę Szkolną Krajową, która sprawowała nadzór nad całym systemem szkolnym na terenie tej dzielnicy (formalnie z wyłączeniem szkolnictwa wyższego). Należy przyznać, że reformy szkolne przeprowadzane przez Radę Szkolną Krajową - co prawda w duchu lojalności wobec monarchii austrowęgierskiej - dawały jednak Polakom duże uprawnienia i możliwości w zakresie rozwijania narodowej kultury i języka.

Szczególnie istotne znaczenie dla rozwoju szkolnictwa w Galicji miała aktywność i polityka oświatowa wiceprezydenta RSK, profesora historii, kojarzonego z grupą młodszych konserwatystów galicyjskich, Michała Bobrzyńskiego. Mimo różnych opinii zarzucających M. Bobrzyńskiemu dążenia do konserwowania dotychczasowej stratyfikacji społecznej w Galicji, trzeba zauważyć, że pod jego przewodnictwem w Radzie (w latach 18901901) i w wyniku realizowanej przez niego polityki oświatowej rozwinięto sieć szkół handlowych i przemysłowych, szkół gimnazjalnych, a przede wszystkim rozszerzono sieć szkół ludowych (choć zróżnicowanych programowo i organizacyjnie), jak też wzmocniono ich kondycję, zdecydowanie podniesiono poziom podręczników szkolnych. W konsekwencji, jego poczynania w edukacji służyły obiektywnie dalszej polonizacji i poprawie jakości galicyjskiej oświaty, a przede wszystkim modernizacji tej dzielnicy polskiej, mocno zapóźnionej w swojej strukturze społeczno-ekonomicznej względem innych ziem polskich i wobec pozostałych części monarchii habsburskiej w pierwszych dekadach autonomii.

Istotną rolę w kreowaniu zmian i ewentualnych dalszych reform w oświacie w zaborze austriackim odegrały dwa lwowskie kongresy pedagogiczne 
(w roku 1894 i 1909). Podczas obrad pierwszego kongresu we Lwowie (1894) wiele uwagi zajęły przede wszystkim zagadnienie wychowania narodowego i sprawa wyższego wykształcenia kobiet. W tej drugiej kwestii wypowiadała się przede wszystkim, znana wówczas działaczka ruchu kobiecego, Kazimiera Bujwidowa15. Należy przypuszczać, że wystąpienia i uchwały kongresu odegrały dużą rolę w przyznaniu kobietom w Galicji prawa do studiów wyższych (w charakterze słuchaczek rzeczywistych - na mocy przepisów z roku 1897 i 1900) ${ }^{16}$.

Sprawa wychowania narodowego zajęła również ważne miejsce podczas obrad Drugiego Polskiego Kongresu Pedagogicznego we Lwowie (1909). Charakterystyczny pozostaje fakt, na który zwraca uwagę np. Czesław Majorek, że kiedy na Zachodzie

środowiska pedagogiczne i oświatowe fascynowały się koncepcjami reorientacji wychowania w duchu haseł liberalizmu, demokratyzmu czy nawet socjalizmu, w podzielonej Polsce do rangi najważniejszej urastał problem wychowania narodowego ${ }^{17}$.

Na Kongresie tym podjęto również wiele innych kwestii, m.in. zagadnienie ustroju i organizacji poszczególnych ogniw systemu szkolnego, zwłaszcza szkoły ludowej, domagając się jednolitości (podobnie jak i seminariów nauczycielskich) ${ }^{18}$.

W zmienionych warunkach historycznych dokonywano reform edukacji na ziemiach polskich w okresie między pierwszą a drugą wojną światową. Po długoletniej niewoli na arenę światową weszła ponownie w pełni suwerenna Polska. Od pierwszych miesięcy niepodległości zasadniczą rolę w projektowaniu i realizacji reform odgrywały organy władzy państwowej. Oczywisty pozostawał bowiem fakt, że oświata i szkolnictwo będą odgrywać $\mathrm{w}$ odrodzonym państwie polskim zasadniczą rolę $\mathrm{w}$ jego odbudowie i wzmacnianiu jego podstaw społeczno-ekonomicznych, w utrwalaniu niepodległości. Uczestniczyły $\mathrm{w}$ tych działaniach reformatorskich także środowiska nauczycielskie i teoretycy wychowania, zgłaszając szereg postulatów i koncepcji, m.in. podczas kongresów i zjazdów pedagogicznych organizowanych w Drugiej Rzeczypospolitej. Szczególną rolę pod tym względem

${ }^{15}$ Zob. Cz. Majorek, W poszukiwaniu aksjomatów narodowego wychowania (Pierwszy Kongres Pedagogiczny we Lwowie w 1894 r.), Przegląd Humanistyczny, 1983, 7, s. 24-25.

16 Zob. m.in.: D. Zołądź-Strzelczyk, W. Jamrożek, Studia z dziejów edukacji kobiet na ziemiach polskich, Poznań 2001, s. 135 i n.

${ }_{17}$ Cz. Majorek, W. Marmon, Dorobek Drugiego Polskiego Kongresu Pedagogicznego we Lwowie (1909 r.), [w:] Prace $z$ historii oświaty $i$ wychowania, red. Z. Ruta, Rocznik NaukowoDydaktyczny, Kraków 1989, s. 131.

18 Księga pamiątkowa II Polskiego Kongresu Pedagogicznego, J. Kornecki, b.m. i d.w., s. 168 i n. 
odegrał Ogólnopolski Zjazd Oświatowy w Warszawie, zorganizowany 1417 kwietnia 1919 roku i zwołany przez Związek Polskich Towarzystw Nauczycielskich, który przeszedł do historii - ze względu na jego znaczenie w określeniu podstaw budowanego wówczas systemu edukacji narodowej pod nazwą Sejmu Nauczycielskiego. Wiele miejsca zajęły podczas obrad kwestie ustroju szkolnego i administracji szkolnej. W tym zakresie do najważniejszych postanowień Zjazdu należało uznanie, że szkoła powszechna powinna być siedmioletnia i jednolita. Przyjęto zarazem, że najniżej zorganizowaną szkołą ma być szkoła o dwóch klasach, posiadająca co najmniej dwóch nauczycieli.

Uchwały i wnioski przyjęte na Sejmie Nauczycielskim nie miały mocy obowiązującej, jednak wytyczały ramy dla prac nad budową demokratycznego systemu edukacji narodowej.

Należy przyznać, że mimo toczących się w Polsce międzywojennej sporów i polemik - m.in. na temat ideału wychowawczego szkoły, treści kształcenia, organizacji systemu szkolnego - stworzono w tym czasie, w istocie od podstaw:

zwarty i nowoczesny, chociaż nie pozbawiony wad system szkolny, obejmujący instytucje oświatowe, wychowawcze, od przedszkola po szkoły wyższe, szkolnictwo ogólnokształcące, zawodowe, artystyczne i specjalne ${ }^{19}$.

Już w pierwszych latach niepodległości władze oświatowe wiele wysił$\mathrm{ku}$ włożyły w unifikację, integrację i repolonizację szkolnictwa wszystkich dzielnic Polski. Spośród pierwszych aktów prawnych, które spełniły ważną rolę w porządkowaniu szkolnictwa w początkowym okresie po odzyskaniu niepodległości, należy wymienić przede wszystkim: dekret o obowiązku szkolnym z 7 lutego 1919 roku, dekret o kształceniu nauczycieli szkół powszechnych także z 7 lutego 1919 roku, Ustawę o tymczasowym ustroju władz szkolnych z 4 czerwca 1920 roku, Konstytucję z 17 marca 1921 roku, a następnie Ustawe o zakładaniu $i$ utrzymywaniu publicznych szkót powszechnych z 17 lutego 1922 roku. Pierwszy wspomniany dokument miał szczególną wage na terenie byłego zaboru rosyjskiego. Wprowadzał bowiem w tej części Polski - nieistniejący dotychczas - obowiązek szkolny, określając zarazem granice wieku szkolnego, sposoby kontroli i realizacji przymusu szkolnego.

Warto także dodać, że na początku niepodległości przyjęto w polskim sejmie Ustawę o szkołach akademickich (13.07.1920), ustalającą jednolity ustrój wszystkich szkół akademickich i poddający je zwierzchniej władzy Ministra

${ }^{19}$ K. Bartnicka, Państwo i edukacja, s. 37. 
Wyznań Religijnych i Oświecenia Publicznego. Dokument ten gwarantował równocześnie prawo wolności nauki i nauczania.

Zręby ustrojowe i programowe polskiego szkolnictwa, ukształtowane już w pierwszych latach po odzyskaniu niepodległości, nie satysfakcjonowały wielu środowisk politycznych i pedagogicznych. Lata dwudzieste w Polsce charakteryzowały się swoistą eksplozją pomysłów na zmiany i reformy szkoły polskiej. Zasadnicze znaczenie dla kształtu zmian w polskim szkolnictwie miała jednak dopiero reforma szkolna, zapoczątkowana ustawami przyjętymi przez Sejm 11 marca 1932 roku: O ustroju szkolnictwa i O prywatnych szkołach. Reforma ta - zwana od nazwiska ówczesnego Ministra WRiOP, Janusza Jędrzejewicza - jędrzejewiczowską, doprowadziła w ciągu kilku kolejnych lat do całościowej przebudowy szkolnictwa i wychowania w Drugiej Rzeczypospolitej. Unifikowała definitywnie szkolnictwo w Polsce i likwidowała ostatnie pozostałości ustawodawstwa oświatowego byłych państw zaborczych.

Wymieniona powyżej Ustawa o ustroju szkolnictwa z 1932 roku regulowała w szczególności zagadnienia dotyczące ustroju i zadań przedszkoli, szkół powszechnych, szkół średnich i zawodowych, kształcenia nauczycieli oraz zasadnicze kwestie odnoszące się do szkolnictwa wyższego. We wstępie do niej - zgodnie z dominującą wówczas w Polsce ideologią wychowania państwowego - podkreślono, że

Ustawa niniejsza wprowadza takie zasady ustroju szkolnictwa, które mają Państwu ułatwić organizację wychowania i kształcenia ogółu na świadomych swych obowiązków i twórczych obywateli Rzeczypospolitej, obywatelom tym - zapewnić jak najwyższe wyrobienie religijne, moralne, umysłowe i fizyczne oraz jak najlepsze przygotowanie do życia, zdolniejszym zaś i dzielniejszym jednostkom ze wszystkich środowisk umożliwić osiągnięcie najwyższych szczebli naukowego i zawodowego wykształcenia ${ }^{20}$.

Reforma jędrzejewiczowska wprowadzała szkolnictwo powszechne podzielone na trzy stopnie organizacyjne i trzy szczeble programowe (szkoła powszechna III stopnia realizowała pełne trzy szczeble programowe; szkoła II stopnia - pierwszy i drugi szczebel programowy oraz najważniejsze składniki szczebla trzeciego; szkoła I stopnia - pierwszy szczebel programowy i wybrane elementy szczebla drugiego i trzeciego). Podstawą dla szkoły średniej ogólnokształcącej - podzielonej na czteroletnie gimnazjum (jednolite pod względem programowym) i dwuletnie liceum (programowo

${ }^{20}$ M. Pęcherski, M. Świątek, Organizacja oświaty w Polsce w latach 1917-1977. Podstawowe akty prawne, Warszawa 1978, s. 412. 
zróżnicowane) - został drugi szczebel programowy szkoły powszechnej (obejmujący nauczanie $\mathrm{w}$ zakresie programu 6 oddziałów). Reforma podniosła zdecydowanie rangę szkolnictwa zawodowego, czyniąc je pełnowartościową częścią systemu szkolnego (wprowadzono m.in. gimnazja i licea zawodowe) ${ }^{21}$.

Na podstawie odrębnej ustawy z 15 marca 1933 roku przeprowadzono także reformę szkolnictwa wyższego. Jej mankamentem było jednak ograniczenie jego dotychczasowej autonomii.

Reforma jędrzejewiczowska została przyjęta z dużą życzliwością podczas obrad III Kongresu Pedagogicznego, zorganizowanego przez Związek Nauczycielstwa Polskiego w dniach 17-21 czerwca 1933 roku. Z analizy treści wystąpień na III Kongresie Pedagogicznym wynika, że twórcy reformy i związanych z nią nowych programów szkolnych

odwołując się do haseł "stulecia dziecka” próbowali połączyć wymogi życia społeczno-państwowego z postulatami psychologii rozwojowej. Zwracali też uwagę na konieczność przystosowania pracy w szkole do potrzeb życia praktycznego i obywatelskiego 22 .

Krytycyzm wobec rezultatów reformy jędrzejewiczowskiej narastał jednak w kolejnych latach, w sytuacji przedłużającego się tzw. kryzysu szkolnego, objawiającego się pozostawaniem dużej części dzieci poza szkołą, wzrostu napięcia politycznego w Polsce i wzrastającego poczucia zagrożenia ze strony Niemiec. Ze szczególną siłą ujawnił się on podczas obrad IV Kongresu Pedagogicznego, zorganizowanego w Warszawie $\mathrm{w}$ dniach 27-29 maja 1939 roku. Domagano się na nim m.in.: zmiany społeczno-kulturalnej treści szkoły, uczynienia podstawą całego systemu szkolnego „przynajmniej 7-letniej szkoły powszechnej poprzedzonej upowszechnionym przedszkolem”, przeprowadzenia "racjonalnej decentralizacji sieci szkół wszystkich typów i stopni z uwzględnieniem właściwości regionalnych i środowiskowych", likwidacji szkół niżej zorganizowanych, zwiększenia liczby szkół średnich państwowych, stworzenia funduszu stypendialnego dla wybitnie uzdolnionych a niezamożnych uczniów szkół średnich i wyższych, rozwoju poradnictwa zawodowego w systemie szkol-

${ }^{21}$ Szerzej w: W. Garbowska, Szkolnictwo powszechne w Polsce w latach 1932-1939, Wrocław 1976; J. Sadowska, Ku szkole na miarę Drugiej Rzeczypospolitej. Geneza, założenia i realizacja reformy jędrzejewiczowskiej, Białystok 2001.

${ }^{22}$ H. Gajdamowicz, Cele wychowania na kongresach $i$ zjazdach pedagogicznych w II Rzeczypospolitej, [w:] Kongresy i zjazdy pedagogiczne w Polsce w XX wieku, red. A. Kicowska, Toruń 2001, s. 37 . 
nym, rozwoju szkolnictwa specjalnego, realizacji kształcenia nauczycieli szkół powszechnych tylko na poziomie szkoły wyższej23.

IV Kongres Pedagogiczny nawiązywał do programu oświatowego Sejmu Nauczycielskiego sprzed dwudziestu lat, stanowiąc swoistą "klamrę” zamykającą wysiłki nauczycieli i związanych z nimi teoretyków o demokratyczne przemiany i reformy oświaty w Polsce międzywojennej. Niestety, wybuch wojny, a następnie lata okupacji niemieckiej i sowieckiej uniemożliwiły weryfikację i próby realizacji jego postulatów oraz żądań dotyczących reformy edukacji narodowej.

Podsumowując rozważania zawarte $\mathrm{w}$ niniejszym artykule, można stwierdzić, że reformy edukacyjne na ziemiach polskich w omawianym czasie były dokonywane w określonym kontekście historycznym i nim w dużej mierze uwarunkowane. Kiedy ich inicjatorem i realizatorem byli zarazem sami Polacy, w czasach istnienia państwa lub jego namiastki, reformy te służyły naprawie, modernizacji bądź wzmocnieniu tego państwa. Ale także wówczas, kiedy w latach niewoli narodowej reformy te inicjowała i przeprowadzała strona polska, miały one również na celu modernizację polskiego narodu i wzmocnienie jego kondycji, tak społecznej, politycznej, jak i ekonomicznej. Oczywiście, w toku projektowania i realizacji reform - nie bez polemik i dyskusji - ważne były też czynniki pedagogiczne. Decydowały one często o konkretnych szczegółowych kwestiach i rozwiązaniach, jednak wydaje się, że w warunkach polskich ustępowały one zdecydowanie pola czynnikom pozapedagogicznym - właśnie: względom politycznym, społecznym, czy ekonomicznym.

\section{BIBLIOGRAFIA}

Bartnicka K., Państwo i edukacja w polskich reformach szkolnych XVIII-XX wieku, [w:] Państwo a edukacja, red. J. Kochanowicz, T. Tokarz, Wrocław 2008.

Gajdamowicz H., Cele wychowania na kongresach $i$ zjazdach pedagogicznych w II Rzeczypospolitej, [w:] Kongresy i zjazdy pedagogiczne w Polsce w XX wieku, red. A. Kicowska, Torun 2001.

Garbowska W., Szkolnictwo powszechne w Polsce w latach 1932-1939, Wrocław 1976.

Jakubiak K., Instytucje samorzadu szkolnego w reformach oświatowych na ziemiach polskich w XIX w. oraz w II Rzeczypospolitej, [w:] Reformy edukacyjne w Polsce, red. I. i G. Michalscy, Skierniewice 2001.

Jobert A., Komisja Edukacji Narodowej w Polsce (1773-1794), Wrocław 1979.

Księga pamiątkowa II Polskiego Kongresu Pedagogicznego, J. Kornecki, b.m. i d.w.

Majorek Cz., W poszukiwaniu aksjomatów narodowego wychowania (Pierwszy Kongres Pedagogiczny we Lwowie w 1894 r.), Przegląd Humanistyczny, 1983, 7.

\footnotetext{
${ }^{23}$ Uchwały IV Kongresu Pedagogicznego, „Głos Nauczycielski” z 1939, 37, s. 851-854.
} 
Majorek Cz., Marmon W., Dorobek Drugiego Polskiego Kongresu Pedagogicznego we Lwowie (1909 r.), [w:] Prace z historii oświaty i wychowania, red. Z. Ruta, Rocznik NaukowoDydaktyczny, Kraków 1989.

Pęcherski M., Świątek M., Organizacja oświaty w Polsce w latach 1917-1977. Podstawowe akty prawne, Warszawa 1978.

Poznański K., Reforma szkolna w Królestwie Polskim w 1862, Wrocław 1968.

Poznański K., Wybrane zagadnienia z historii wychowania, t. 2, Warszawa 2006.

Sadowska J., Ku szkole na miarę Drugiej Rzeczypospolitej. Geneza, założenia i realizacja reformy jędrzejewiczowskiej, Białystok 2001.

Smołalski A., Teleologia reform edukacyjnych w nowożytnej Europie $i$ w Polsce, [w:] Reformy edukacyjne w Polsce, red. I. i G. Michalscy, Skierniewice 2001.

Suchodolski B., Komisja Edukacji Narodowej na tle roli oświaty w dziejowym rozwoju Polski, Warszawa 1973.

Uchwały IV Kongresu Pedagogicznego, „Głos Nauczycielski” z 1939, 37.

Winiarz A., Szkolnictwo Księstwa Warszawskiego i Królestwa Polskiego (1807-1831), Lublin 2002.

Żołądź-Strzelczyk D., Jamrożek W., Studia z dziejów edukacji kobiet na ziemiach polskich, Poznań 2001. 